\title{
Physiological Significance of the Weigh-In during Live-Release Angling Tournaments for Largemouth Bass
}

\author{
Cory D. Suski* and Shaun S. Killen \\ Department of Biology, Queen's University, Kingston, Ontario K7L 3N6, Canada \\ Steven. J. Cooke \\ Center for Aquatic Ecology, Illinois Natural History Survey, \\ and Department of Natural Resources and Environmental Sciences, \\ University of Illinois, 607 East Peabody Drive, Champaign, Illinois 61820, USA
}

JAMES D. KIEFFER

Department of Biology, Centre for Coastal Studies, University of New Brunswick, Post Office Box 5050, Saint John, New Brunswick E2L 4L5, Canada

\section{DAVID P. PHILIPP}

Center for Aquatic Ecology, Illinois Natural History Survey, and Department of Natural Resources and Environmental Sciences, University of Illinois, 607 East Peabody Drive, Champaign, Illinois 61820, USA

\author{
BRUCE L. TUfTS
}

Department of Biology, Queen's University, Kingston, Ontario K7L 3N6, Canada

\begin{abstract}
In the current study, we simulated different components of a live-release angling tournament (angling, live-well confinement, and weigh-in) to determine the relative physiological significance of these tournament components for largemouth bass Micropterus salmoides. Our results indicated that depletions of white muscle energy stores and accumulations of muscle lactate (i.e., a large metabolic disturbance) are the most important consequences of live-release angling tournaments for largemouth bass. This study also showed that there are two distinct components of a live-release tournament that cause a metabolic disturbance in largemouth bass: angling and the weigh-in. While the physiological consequences of angling are already well understood, this is the first study to show that the weigh-in portion of a live-release tournament also causes a large anaerobic disturbance in largemouth bass. In our simulation, the weigh-in resulted in a $75 \%$ decrease in white muscle phosphocreatine, a $46 \%$ decrease in ATP, and a $62 \%$ decrease in glycogen relative to control largemouth bass. The weigh-in simulation also caused the lactate concentration in white muscle to increase by about sevenfold relative to control fish and resulted in significant changes to cardiac function. Based on these results, subsequent experiments were performed to determine the main factor(s) responsible for the metabolic disturbance that results from the weighin. These experiments demonstrated that the period of air exposure during the weigh-in was a major cause of this disturbance. We recommend that tournament organizers minimize the air exposure that largemouth bass receive during the weigh-in to improve the physiological condition of released tournament-caught fish.
\end{abstract}

Competitive angling events have become increasingly widespread in the past several decades; at least 30,000 events occur annually across North America (Shupp 1979; Schramm et al. 1991; Kerr and Kamke 2003). Despite their potential benefits (Schramm et al. 1991; Pereira et al. 2002), liverelease angling tournaments for largemouth bass Micropterus salmoides may have negative biolog-

\footnotetext{
* Corresponding author: suskic@ biology.queensu.ca

Received August 7, 2003; accepted May 26, 2004
}

ical impacts on fish populations (Schramm et al. 1991; Hayes et al. 1995; Wilde 1998). Estimates of total mortality for largemouth bass tournaments range from $0 \%$ to $61 \%$ of fish caught (Wilde 1998), and several studies have attempted to correlate tournament mortality with factors such as season (Lee et al. 1993; Kwak and Henry 1995), wind speed (Goeman 1991; Fielder and Johnson 1994), air or water temperature (Schramm et al. 1985; Schramm et al. 1987; Bennett et al. 1989), and organizational procedures (Lee et al. 1993; Weathers and Newman 1997). While each of these in- 
dividual factors may indirectly influence mortality, the underlying physiological mechanisms responsible for tournament mortality have not been clearly identified.

During an angling tournament, many factors may contribute to physiological disturbances in fish. For example, angling normally involves burst (anaerobic) exercise, as well as air exposure during hook removal (Payer et al. 1989; Gustaveson et al. 1991; Ferguson and Tufts 1992; Kieffer et al. 1995). To keep fish alive during the angling day, anglers typically retain fish in on-board live wells supplied with fresh lake water. Nevertheless, fish may be exposed to several stressors, including hypoxia (Hartley and Moring 1993), temperature change (Plumb et al. 1988), crowding (Cooke et al. 2002), and accumulation of metabolic wastes (Kwak and Henry 1995). Fish also may experience an additional physiological disturbance during the weigh-in process. At the weigh-in, fish are normally confined in water-filled plastic bags while being transferred from the live well to the weighin staging area, and are then exposed to air while being weighed on a scale.

Suski et al. (2003) recently showed that the most important physiological change that occurred in tournament-caught largemouth bass was a large metabolic disturbance characterized by depletion of muscle energy stores and accumulation of lactate in plasma and white muscle. At present, however, the relative contributions of the different components of a live-release angling tournament toward the observed physiological disturbances in fish are unknown.

In this study, our first objective was to determine the relative physiological impact of the different components of a live-release angling tournament. To do so, we assessed changes in the physiology of largemouth bass during experimental simulations of different components of a live-release tournament. We hypothesized that the period of live-well confinement for many tournamentcaught fish would be sufficiently long to permit recovery from the metabolic disturbances associated with angling (i.e., clearance of lactate, replenishment of energy stores, etc.) (see Gustaveson et al. 1991; Wood 1991; Wang et al. 1994a; Milligan 1996), and that other aspects of live-release tournaments must therefore contribute to the large metabolic disturbance observed in largemouth bass at the end of the tournament day (Suski et al. 2003). Preliminary results from this simulation experiment showed that the weigh-in was an important factor contributing to the physiological dis- turbance in tournament fish. We therefore conducted a second series of experiments to examine the significance of a potentially important aspect of the weigh-in procedure-the period of air exposure. We hypothesized that the period of air exposure during the weigh-in would be a significant factor contributing to the physiological disturbance in tournament fish. Both series of experiments involved the sampling of blood, tissue, and cardiac parameters of largemouth bass exposed to experimental manipulations.

\section{Methods}

Experiments were carried out from June to September of 2002 at the Queen's University Biological Station (QUBS) on Lake Opinicon, Ontario $\left(44^{\circ} 31^{\prime} \mathrm{N}, 76^{\circ} 20^{\prime} \mathrm{W}\right)$. During experiments, water temperatures at QUBS ranged from $22^{\circ} \mathrm{C}$ to $24^{\circ} \mathrm{C}$ and averaged $23^{\circ} \mathrm{C}$. All largemouth bass used in the study were angled by use of standard gear from lakes in southeastern Ontario, and were held in laboratory holding tanks for $24-48 \mathrm{~h}$ prior to experimentation. Previous work has shown that, after $24 \mathrm{~h}$ of recovery time, fish have fully recovered from the physiological disturbances (i.e., depletion of energy stores, accumulation of lactate, etc.) that arise from angling and exercise (Gustaveson et al. 1991; Wood 1991; Wang et al. 1994b; Milligan 1996; Kieffer 2000; C. D. Suski and B. L. Tufts, unpublished data). The mean size of the fish used in these experiments was $327.2 \mathrm{~mm}$ total length (SE, $6.2 \mathrm{~mm} ; N=57)$ and $506.8 \mathrm{~g}(\mathrm{SE}, 31.4 \mathrm{~g}$; $N=57$ ). Although sample sizes for each experiment were within the range of those used in similar in vivo physiological experiments (Wang et al. 1994a; Richards et al. 2002), it is also important to point out that, in accordance with the spirit of current Animal Care Guidelines at Queen's University, we attempted to use the minimum number of wild specimens for these experiments.

\section{Series I: Tournament Simulation Experiment}

Series I was divided into two parallel experiments: terminal blood and tissue sampling and in vivo monitoring of cardiac output.

Blood and muscle sampling: control.-Largemouth bass were moved from a common holding tank in the laboratory to individual flow-through, black perspex boxes supplied with aerated freshwater, where fish were held for 24-48 h before sampling (Suski et al. 2003). Immediately prior to sampling, we terminated the flow of water to the boxes and added a buffered mixture of anesthetic (3-aminobenzoic acid ethyl ester methanesulfonate 
[MS-222]) to each box. The concentrations in the anesthetic solution were $250 \mathrm{mg} / \mathrm{L}$ for MS-222 and $500 \mathrm{mg} / \mathrm{L}$ for $\mathrm{NaCO}_{3}$ (Summerfelt and Smith 1990; Booth et al. 1995). Once the largemouth bass had lost equilibrium and ceased ventilation (about 1.5 min), we collected blood and tissue samples.

We obtained blood samples by puncturing the caudal vessel with an 18-gauge needle and heparinized syringe (Summerfelt and Smith 1990). Blood was withdrawn from the vessel, transferred to a $1.5-\mathrm{mL}$ microcentrifuge tube, and immediately centrifuged for $1 \mathrm{~min}$. We then used a pipette to draw the plasma (supernatant) from the corpuscular portion of the blood. Both plasma and erythrocytes were stored in the field in liquid nitrogen and transferred to a $-80^{\circ} \mathrm{C}$ freezer in the laboratory.

For tissue sampling, we removed about 5-10 g of white muscle from the epaxial musculature behind the operculum and above the lateral line. We immediately freeze-clamped the muscle samples in aluminum tongs that were precooled in liquid nitrogen, wrapped the samples in aluminum foil, and then transferred them to a dewar containing liquid nitrogen, where they were held until our return to the laboratory. This method of tissue preparation results in preservation of energy metabolites and prevents the accumulation of waste products from sampling-induced activity (Wang et al. 1994b). Once in the laboratory, we removed the samples from the dewar and stored them in a $-80^{\circ} \mathrm{C}$ freezer until processing (Booth et al. 1995). The time required for the collection of blood and tissue after the fish had ceased to ventilate was normally less than $30 \mathrm{~s}$.

Blood and muscle sampling: angling simulation.-The next component of the experiment was intended to simulate the physical activity that fish experience during angling. Our main objective during this component was to produce a significant anaerobic disturbance in the fish so that we could examine what happened to this disturbance during other components of our tournament simulation. It was also important for us to reproduce a similar anaerobic disturbance in all fish involved in these experiments. Because the physiological disturbance caused by angling is very similar to the physiological response to other forms of burst (anaerobic) exercise (Gustaveson et al. 1991; Wood 1991; Kieffer et al. 1995), we chose to manually chase the fish for $1 \mathrm{~min}$ to produce an anaerobic disturbance that would be similar to that caused by an angling bout.

For this component, we carefully netted large- mouth bass from a holding tank and transferred them to a tank filled with fresh lake water. Following 1 min of manual chasing, we transferred the fish to a container of lake water containing the anesthetic mixture. Following cessation of ventilation, we sampled the fish for blood and tissues.

Blood and muscle sampling: live-well confinement.-To simulate live-well confinement, we netted largemouth bass from a holding tank, exercised them as described above, and then transferred them to a live well on board a recreational angling boat. On three different days, groups of four largemouth bass were held in the live well for $6 \mathrm{~h}$ at densities of $40.8 \pm 1.3 \mathrm{~g} / \mathrm{L}$ (SE). We remained on board the boat during this portion of the experiment to replicate typical tournament activities (i.e., drive the boat, angle, etc.). Every $20 \mathrm{~min}$, we turned the live-well aerator on for a duration of $10 \mathrm{~min}$. This served to add fresh lake water to the live well and to aerate the live-well water via the spraying of fresh water. At the end of the confinement period, we added anesthetic to the live well. Once the fish had completely lost equilibrium, we sampled them for blood and tissues as described above. Of the largemouth bass contained in the live well on a particular day, two were sampled as part of the live-well treatment, and two were removed and sampled as part of the weigh-in treatment. Fish used in the weigh-in treatment (see below) were removed prior to the addition of anesthetic to the live well, and care was taken not to disturb fish used in the live-well treatment when weigh-in treatment fish were removed. Water temperatures during all periods of live-well confinement, both at the surface of the lake and inside the live well, ranged from $22^{\circ} \mathrm{C}$ to $24^{\circ} \mathrm{C}$.

Blood and muscle sampling: weigh-in simulation.-For the next experimental component, fish were exercised for $1 \mathrm{~min}$, confined in a live well for $6 \mathrm{~h}$ (see previous section), netted from the live well, transferred in clear plastic bags $(20 \mathrm{~L}$ of lake water), and held in the bags for 5 min to simulate tournament conditions prior to weighing the fish. Next, the fish were emptied into a plastic laundry basket that drained quickly, were exposed to air for $1 \mathrm{~min}$, and then were anaesthetized prior to collection of blood and muscle. The duration of air exposure and confinement in transport bags approximated the duration measured in live-release tournaments in southeastern Ontario (C. D. Suski and B. L. Tufts, unpublished data).

Blood and muscle sampling: recovery.-The final component we examined in this experiment was a recovery group. For this component, large- 
mouth bass received all of the treatments described above, were placed in darkened perspex boxes for $24 \mathrm{~h}$ to recover, and were then sampled for blood and tissue.

Blood and muscle sampling: analyses.-Analyses for plasma and white muscle variables are described in detail in Booth et al. (1995) and in Suski et al. (2003). We quantified plasma osmolarity with a freezing-point depression osmometer (Advanced Instruments, Inc., model 3M0). Plasma lactate concentration was quantified with a commercially available lactate assay (Sigma-Aldrich Co., product number 826-A) that followed the methods of Lowry and Passonneau (1972).

We used the enzymatic assay methods of Lowry and Passonneau (1972) to perform analyses of tissue lactate, phosphocreatine (PCr), and ATP concentrations after processing the muscle according to the procedure described in Booth et al. (1995). An additional portion of muscle tissue was used to measure glycogen according to the method of Hassid and Abraham (1957).

The total anaerobic energy expenditure (AEE) in ATP equivalents within the white muscle of fish from each treatment group was calculated as

$$
\mathrm{AEE}=(\Delta \text { lactate } \times 1.5)+\Delta \mathrm{ATP}+\Delta \mathrm{PCr},
$$

where $\Delta$ represents the change from control values, 1.5 ATP units are generated per unit of lactate produced, and $1 \mathrm{PCr}$ unit is equal to 1 ATP unit (Pearson et al. 1990; McDonald et al. 1998).

Cardiac variables.-In addition to blood and tissue sampling, we also monitored cardiac variables during a simulated live-release angling tournament (Cooke et al. 2001; Schreer et al. 2001; Cooke et al. 2003). Both control and recovery values of cardiac activity were obtained by 5 -min monitoring of fish in 75-L aquaria supplied with a continuous flow of lake water. We again simulated the angling portion of the experiment in an oval tank, and fish were chased for $1 \mathrm{~min}$, following which their cardiac activity was monitored for $5 \mathrm{~min}$.

The collection of cardiac variables required the lead wire from the silicone cuff-type Doppler flow probe to remain attached to the fish throughout the experiment. The lead wire was about $1 \mathrm{~m}$ in length; therefore, placing all experimental fish into one common live well would have resulted in the possibility of lead wire entanglement and/or damage to the aorta. As a result, the live-well portion of the experiment could not be conducted by placing all fish in one common live well, and we therefore carried out this component on board a 6-m pontoon boat upon which eight individual live wells were constructed. The simulated live wells consisted of plastic containers (about $50 \mathrm{~L}$ of water in volume), each with a tight-fitting lid. Freshwater was delivered to the live wells by a pump submerged in the lake at a depth of about $0.75 \mathrm{~m}$. Each live well contained one subject fish (mean weight $\pm \mathrm{SE}=$ $571.9 \pm 49.7 \mathrm{~g})$ that was monitored for cardiac output, and one companion fish (mean weight $=$ $381.2 \pm 44.7 \mathrm{~g}$ ) added to the live well to increase fish density. Once the pontoon boat had returned to the dock after $6 \mathrm{~h}$ of driving, the cardiac activity of each subject fish was recorded for $5 \mathrm{~min}$.

Following experimentation, we euthanatized all fish outfitted with Doppler flow cuffs with an overdose of anesthetic (180 mg clove oil/L), and we conducted a postmortem calibration to convert Doppler shift (V) to actual blood flow ( $\mathrm{mL} / \mathrm{min})$ (see Cooke et al. [2001] and Schreer et al. [2001] for details). Pig blood perfused through the aorta was used to calibrate the probes over a range of flow rates encompassing those recorded during the trials. Reference flow rates were analyzed with linear least squares regression.

\section{Series II: Weigh-In Experiments}

The second series of experiments involved a simulated weigh-in to examine the relative importance of air exposure during the weigh-in procedure. As with the tournament simulation portion of the study, our examination of the weigh-in was also divided into two parallel experiments: terminal blood and tissue sampling, and in vivo monitoring of cardiac output. All experimental procedures for blood and tissue sampling and cardiac monitoring were identical to those described above for the first series of experiments.

For these experiments, we carefully netted all fish from a common holding tank in the laboratory and quickly transferred them to a plastic bag containing $20 \mathrm{~L}$ of lake water. Fish were held in the plastic bag for 5 min to replicate an angler transporting fish from a boat to the weigh-in stage. Following this 5-min period, we randomly assigned fish to one of two different treatment groups: air or water.

Largemouth bass in the air treatment group were transferred from the plastic bag to a laundry basket as in the previous series of experiments. We left these fish air exposed in the laundry basket for 1 min, and then transferred them directly to a container of buffered anesthetic at concentrations listed above and sampled them for plasma and tissue. Largemouth bass in the water treatment were trans- 
ferred from the plastic bag to a container of lake water, and we left them in the container of lake water for $1 \mathrm{~min}$. These fish were then transferred directly (without air exposure) to a container of buffered anesthetic and were sampled for plasma and tissue. Largemouth bass used in the cardiac output series of experiments were continuously monitored during similar air and water treatments, and we further monitored them for $2 \mathrm{~h}$ following return to perspex boxes.

\section{Statistical Methods}

We performed comparisons of all blood and tissue analyses across components in series I using a one-way analysis of variance (ANOVA) followed by a Dunnett's test comparing treatment means to the control means (Zar 1999). The AEE of largemouth bass from the different treatments in the weigh-in simulation (series II) were compared by use of a $t$-test, and the AEE of fish from the tournament simulation (series I) were compared with a one-way ANOVA followed by a posthoc Student's $t$-test (Sokal and Rohlf 1995). We used a one-way repeated-measures ANOVA followed by a post hoc Student's $t$-test (Sokal and Rohlf 1995) to compare the results from the cardiac output portion of the tournament simulation experiment. Results from the cardiac output portion of the series II experiments were examined by use of a two-way repeated measures ANOVA (main effects: treatment group and time) followed by a post hoc Student's $t$-test (Sokal and Rohlf 1995). Analyses were performed with the software JMPIN 4.0 (SAS Institute, Inc.). We report all means with SE values, and the level of significance $(\alpha)$ for all tests was 0.05 .

\section{Results}

\section{Tournament Simulation Experiments}

The angling simulation resulted in decreases of 75,46 , and $62 \%$ for white muscle PCr, ATP, and glycogen, respectively, relative to control fish (Figure 1A-C). After live-well confinement, energy stores recovered to resting control levels (Figure $1 \mathrm{~A}-\mathrm{C})$. The weigh-in simulation caused a second significant decrease in energy stores, but values were restored following $24 \mathrm{~h}$ of recovery (Figure $1 \mathrm{~A}-\mathrm{C})$. Similarly, following the exercise component, concentrations of lactate in white muscle increased $315 \%$, and concentrations of lactate in plasma increased nearly fivefold (Figure 2A, B). These disturbances returned to resting control levels with live-well confinement, but again showed significant increases after the weigh-in simulation
A

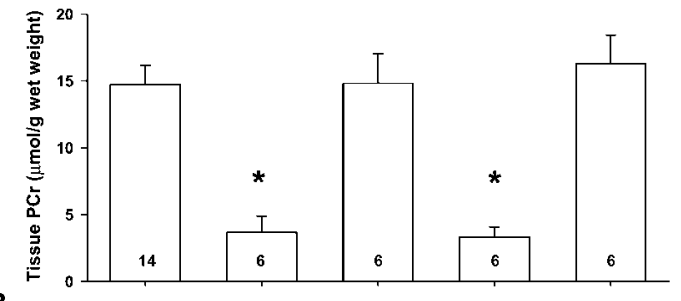

B

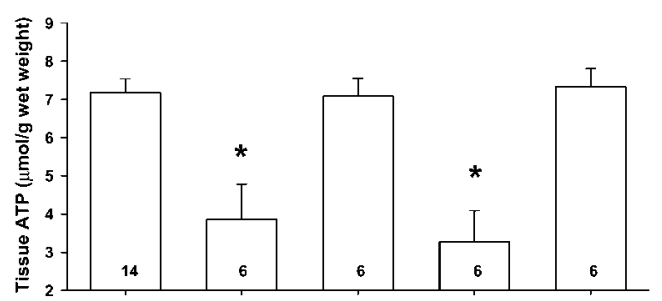

C

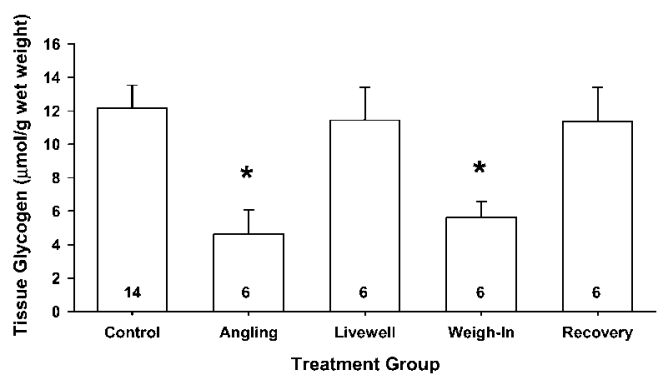

FiguRE 1.-Tissue concentrations of (A) phosphocreatine (PCr), (B) ATP, and (C) glycogen in largemouth bass sampled after different components of a simulated live-release angling tournament. Error bars show $1 \mathrm{SE}$, and sample sizes for the different components are given on each bar. Asterisks denote significant differences from the control group (ANOVA; Dunnett's test, $P<$ $0.05)$.

(Figure 2A, B). Twenty-four hours of recovery, however, allowed lactate concentrations in both white muscle and plasma to return to control levels (Figure 2A, B). Furthermore, following the exercise and weigh-in components of the experiment, the AEE of largemouth bass was over 30 times greater than for the live-well and recovery components (Figure 3 ).

Following the exercise bout, there was a significant (15\%) increase in plasma osmolarity (Figure 4A). The osmotic disturbance associated with the angling simulation was corrected, however, after live-well confinement (Figure 4A). A second significant increase in plasma osmolarity was observed following the weigh-in simulation, but recovery allowed plasma osmolarity to return to control levels (Figure 4A). During the tournament simulation, the concentrations of plasma chloride 
A

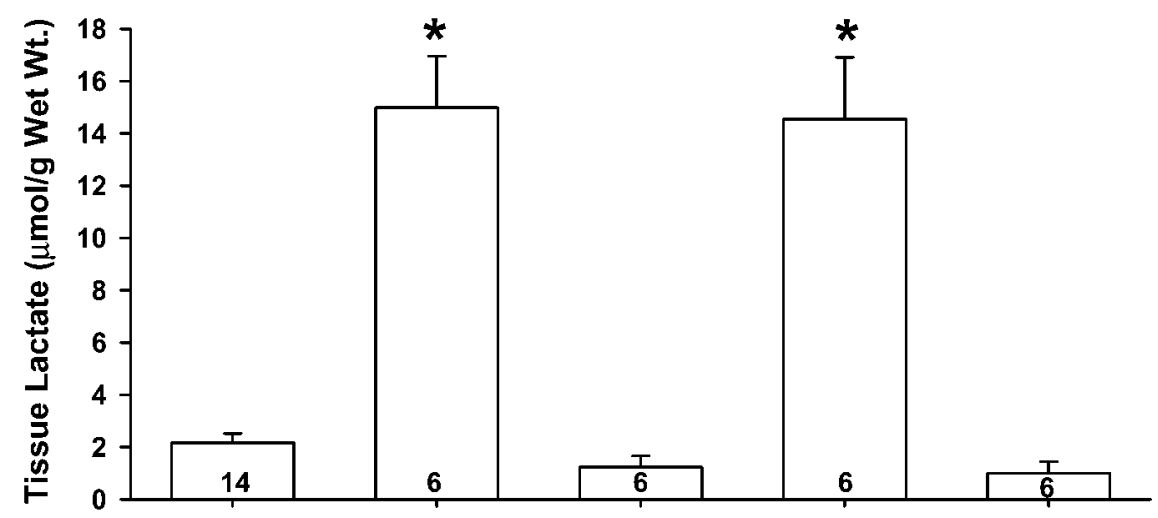

B

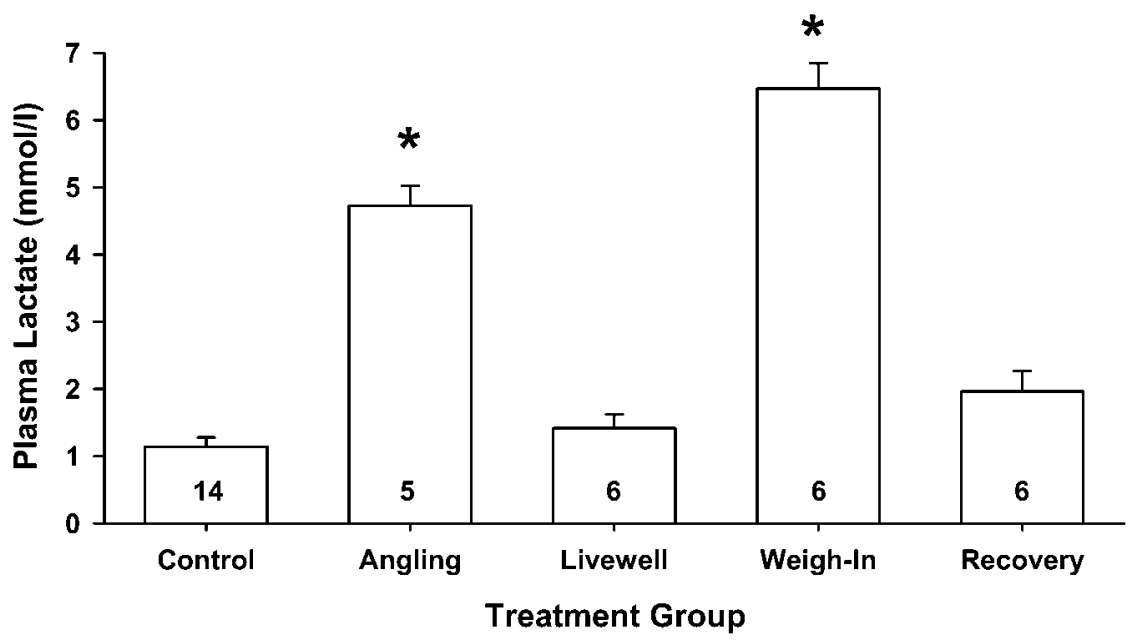

FIgURE 2.-(A) Tissue lactate and (B) plasma lactate concentrations in largemouth bass sampled after different components of a simulated live-release angling tournament. Error bars show $1 \mathrm{SE}$, and sample sizes for the components are given on each bar. Asterisks denote significant differences from the control group (ANOVA; Dunnett's test, $P<0.05)$.

in all components did not differ significantly from control values (ANOVA, $P>0.05$, Figure 4B).

Following the angling simulation, live-well treatment, and weigh-in treatment, the cardiac output of largemouth bass was elevated by about $40 \%$ relative to control individuals (Figure 5A). This disturbance was primarily driven by significant increases in heart rate at these sampling times (Figure 5B). After a 24-h recovery, all three cardiac parameters had returned to resting control levels (Figure 5A-C). No mortality was observed following any portion of the tournament simulation.

\section{Weigh-In Experiments}

During the weigh-in simulations, PCr fell by $83 \%$ in air-exposed largemouth bass and $40 \%$ in non-air-exposed largemouth bass (Figure 6A). Similarly, tissue ATP concentrations fell by $50 \%$ in largemouth bass that were exposed to air during the weigh-in and 30\% in fish that were not exposed to air (Figure 6B). Tissue glycogen concentrations in non-air-exposed fish were not significantly different from control values, but glycogen fell by $66 \%$ in air-exposed fish (Figure 6C).

Air exposure during the weigh-in resulted in a sevenfold increase in tissue lactate concentration relative to control values (Figure 7A). When largemouth bass were not exposed to air during the weigh-in, however, tissue lactate concentrations did not differ significantly from control levels (Figure 7A). Plasma lactate increased by 2.7 $\mathrm{mmol} / \mathrm{L}$ in air-exposed fish, but increased only by 


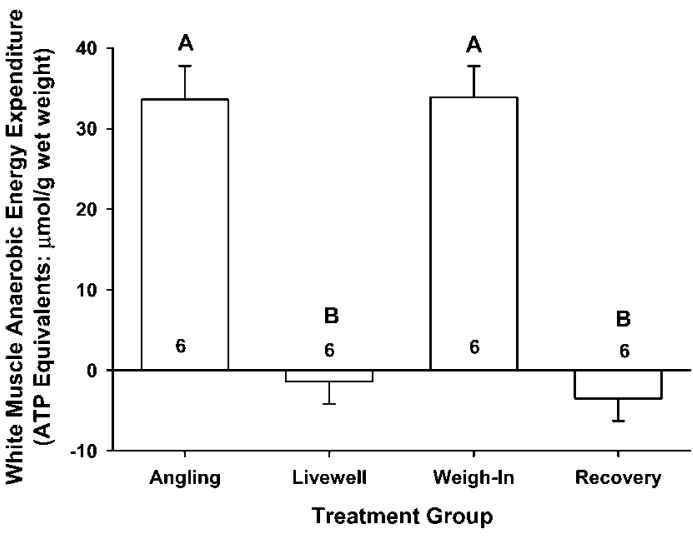

FIGURE 3.-White muscle anaerobic energy expenditure of largemouth bass sampled after different components of a simulated live-release angling tournament. Error bars show $1 \mathrm{SE}$, and sample sizes for the different components are given on each bar. Values with differing letters are significantly different (ANOVA; post hoc Student's $t$-test, $P<0.05)$.

$1.6 \mathrm{mmol} / \mathrm{L}$ in non-air-exposed fish (Figure 7B). The AEE of largemouth bass receiving air exposure during the weigh-in simulation $(38.2 \pm 2.4$ ATP equivalents $[\mu \mathrm{mol} / \mathrm{g}$ wet weight]) was also more than double that of the control group (14.7 \pm 3.3 ATP equivalents).

During the weigh-in simulation of series II, the cardiac output of largemouth bass increased significantly once the fish were transferred from the holding tank to the plastic transport bag (Figure $8 \mathrm{~A})$. For fish that were not exposed to air during the weigh-in, cardiac output remained elevated for $0.5-1.0 \mathrm{~h}$, then returned to control levels. In contrast, fish that received air exposure during the weigh-in exhibited a significantly lower cardiac output during the air exposure period, followed by a significant increase in cardiac output when returned to the recovery chamber. The cardiac output of air-exposed fish required $1.0-1.5 \mathrm{~h}$ to return to resting levels (Figure 8A). These differences in cardiac output resulted mainly from increases in heart rate. During the recovery period, the heart rate of air-exposed largemouth bass was significantly greater than that of non-air-exposed fish (Figure 8B). Air-exposed fish also exhibited a significant decline in stroke volume relative to control values that was absent in fish that remained in water (Figure 8C).

\section{Discussion}

Our current results support recent findings of Suski et al. (2003) and provide further evidence that live-release angling tournaments cause a significant metabolic disturbance in largemouth bass. This is the first study, however, to show that there are two distinct components of a live-release tournament that cause severe bouts of anaerobic activity in fish. In our experiments, both the angling simulation and the weigh-in caused large reductions in muscle energy stores and accumulations of lactate. Physiological changes of this nature occur in fish following such disturbances as exhaustive (anaerobic) exercise (Wood 1991; Wang et al. 1994a; Kieffer et al. 1995; Schreer et al. 2001), air exposure (Ferguson and Tufts 1992; Cooke et al. 2001), and hypoxia (Boutilier et al. 1988). In each of these situations, an inadequate oxygen supply forces tissues to use anaerobic glycolysis to meet ATP demands.

The physiological changes caused by the angling simulation in the present study were very similar to those of angled fish in previous studies (Gustaveson et al. 1991; Wood 1991; Kieffer et al. 1995; Cooke et al. 2000; Suski et al. 2003). Previous studies have also shown that the magnitude of the postangling disturbance is influenced by the duration of the angling bout (Gustaveson et al. 1991; Kieffer et al. 1995). Given that professional tournament anglers strive to land fish as quickly as possible, it is likely that the magnitude of the physiological disturbances exhibited by fish angled in many tournament situations is lower than that created in the present simulation. In the present study, our objective during the angling simulation was simply to create an anaerobic disturbance in the fish similar to that caused by a significant angling bout, so that we could determine whether the fish were able to recover from this disturbance during the subsequent components of the tournament. The changes in muscle metabolites during this component of our experiment clearly indicated that we achieved this objective.

There was little evidence from the variables measured that the period of live-well confinement caused an additional physiological disturbance in the fish. These results are somewhat surprising, because the results of previous studies (Hartley and Moring 1993; Kwak and Henry 1995; Eros and Milligan 1996) suggest that live-well confinement could have a negative impact on the physiological condition of tournament-caught fish. In contrast, our results indicate that largemouth bass held within a live well can recover from the disturbance caused by angling if an appropriate set of environmental conditions is provided. Although the fish in our study were exposed to moderate 
A
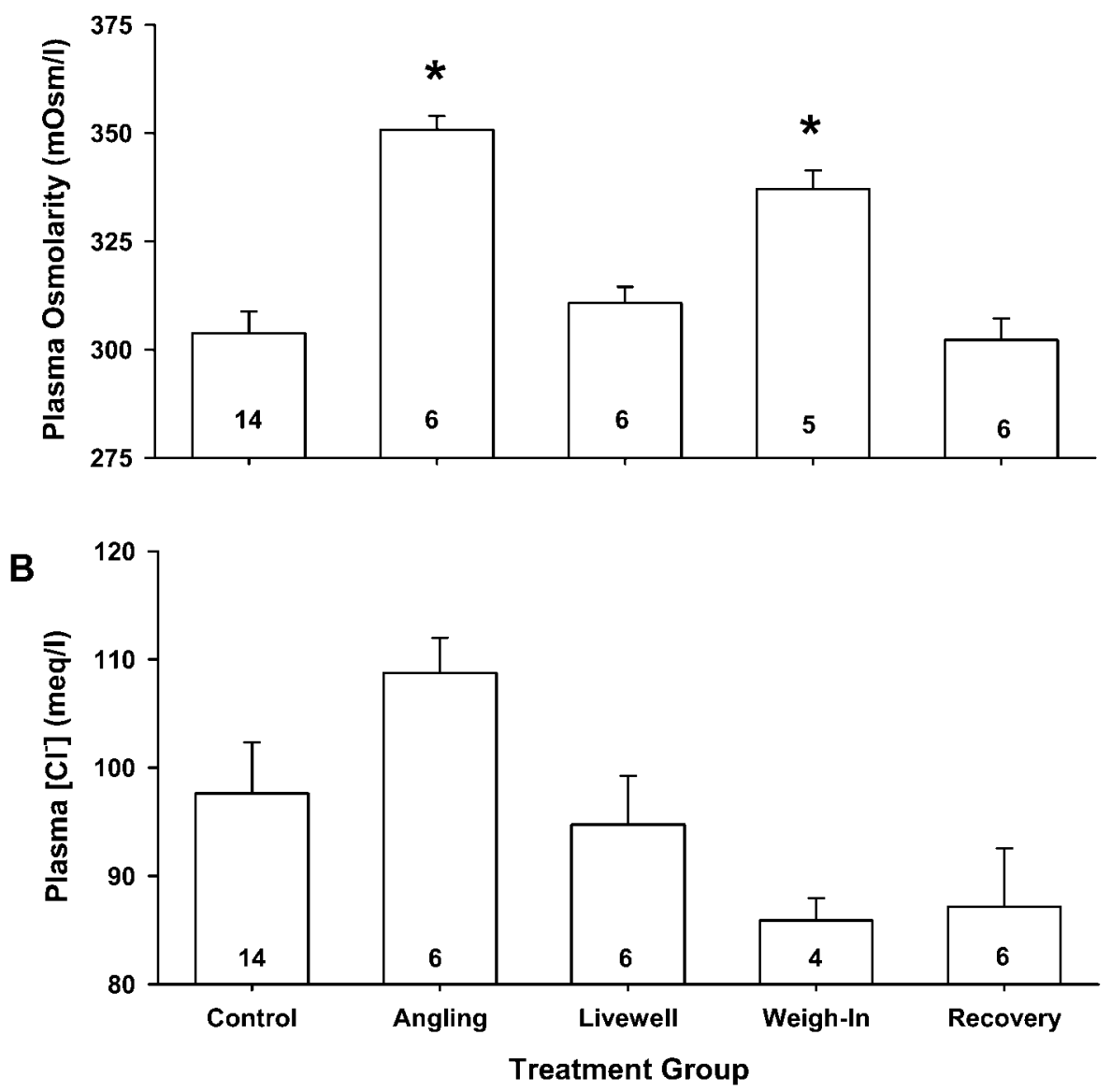

FIGURE 4.-(A) Plasma osmolarity and (B) plasma chloride concentration in largemouth bass sampled after different components of a simulated live-release angling tournament. Error bars show 1 SE, and sample sizes for the different components are given on each bar. Asterisks denote significant differences from the control group (ANOVA; Dunnett's test, $P<0.05$ ).

crowding in the live well and were frequently disturbed, it is likely that physiological recovery from exercise was possible because the live-well water quality was maintained within reasonable limits by our consistent aeration/flushing schedule, and because water temperatures were not near critical levels for this species. Recovery from exhaustive exercise involves the clearance of metabolic wastes, replenishment of energy stores, and the correction of osmotic and acid/base imbalances (Wood 1991; Wang et al. 1994a). These recovery processes appear to be fueled by the oxidation of lipids (Richards et al. 2002) and require an aerobic environment to support an increase in oxygen consumption (Scarabello et al. 1991). While our results indicate that largemouth bass are capable of full recovery from angling during live-well con- finement, an important goal of future studies in this area will be to clearly determine the critical thresholds of water quality (e.g., oxygen, temperature, etc.) and live-well density that must be maintained to allow physiological recovery from angling to take place.

Interestingly, the nature and magnitude of the subsequent physiological disturbance were very similar between the simulated weigh-in and the angling simulation. The physiological condition of the fish following the weigh-in simulation in the present study was also very similar to that of fish sampled immediately after real tournaments (Suski et al. 2003). These results indicate that the weighin procedure in live-release tournaments causes another major bout of anaerobic activity comparable to that caused by a significant bout of burst 
A
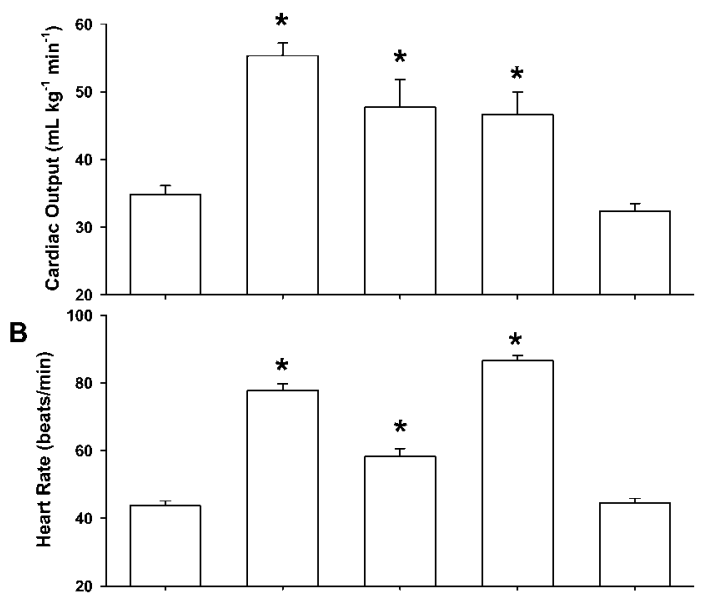

C

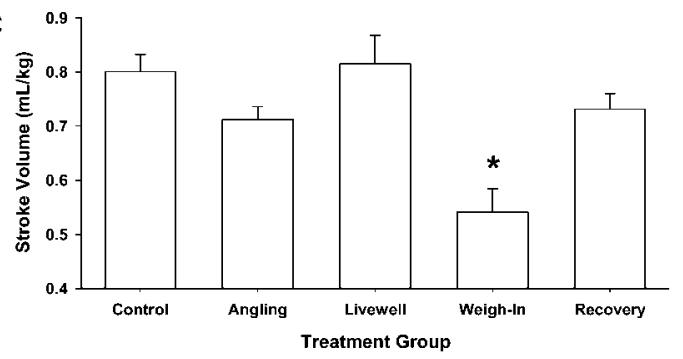

Figure 5.-(A) Cardiac output, (B) heart rate, and (C) stroke volume of largemouth bass $(N=8)$ sampled after different components of a simulated live-release angling tournament. Error bars show $1 \mathrm{SE}$, and asterisks denote significant differences from the control group (repeated-measures ANOVA; post hoc Student's $t$-test, $P<0.05)$.

(exhaustive) exercise. These findings can be explained by the procedures currently involved in the weigh-in during most live-release tournaments. The weigh-in process typically involves an extended period of air exposure, during which the fish may also undergo substantial physical activity. Even relatively brief periods of air exposure in combination with physical activity have been shown to have serious physiological consequences for fish (Ferguson and Tufts 1992). Depending upon the weight of fish and the water temperature, the transfer bags used to bring the fish to the weigh-in site in real tournaments may also become hypoxic within a relatively short period of time if adequate precautions are not taken (C. D. Suski and B. L. Tufts, unpublished data). Taken together, these findings indicate that in many live-release tournaments, the weigh-in may actually be the most challenging component for the fish. We also acknowledge, however, that certain environmental
A

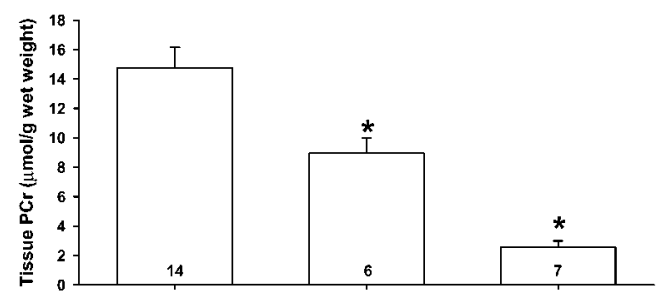

C
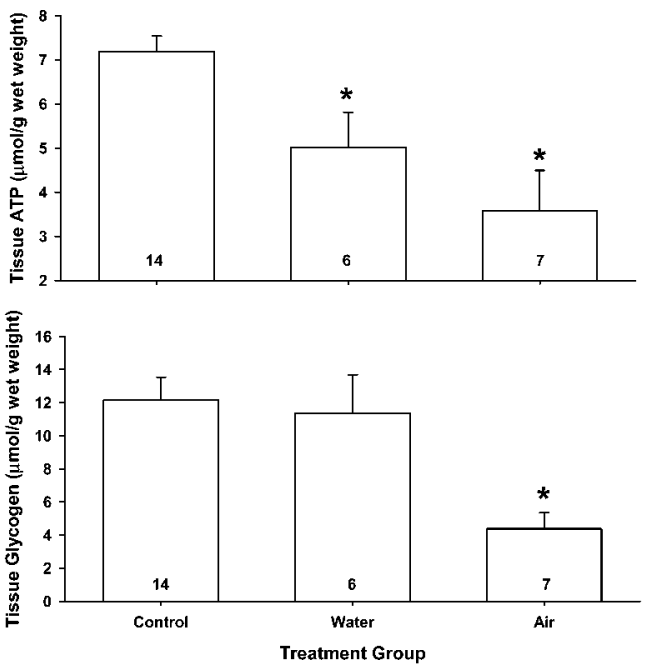

FIgURE 6.-Tissue concentrations of (A) phosphocreatine (PCr), (B) ATP, and (C) glycogen in largemouth bass sampled after either air or water exposure during a simulated angling tournament weigh-in. Error bars show $1 \mathrm{SE}$, and sample sizes for the different components are given on each bar. Asterisks denote significant differences from the control group (ANOVA; Dunnett's test, $P<0.05$ ).

conditions (e.g., extreme temperatures, waves, etc.) will likely influence the magnitude of the physiological disturbance during some tournament components, such as live-well confinement.

The results of our second series of experiments demonstrated that the anaerobic disturbance arising from the weigh-in is largely a result of the prolonged air exposure during this component of a tournament. Largemouth bass that were exposed to air during the weigh-in exhibited greater physiological disturbances than non-air-exposed fish. The values for muscle energy reserves and lactate measured following the weigh-in simulation were also comparable in magnitude to variables measured after the weigh-in of actual live-release tournaments (Suski et al. 2003), indicating that this simulation accurately replicated actual conditions. These results clearly indicate that efforts to minimize or eliminate air exposure during the weighin process of live-release tournaments would prob- 
A

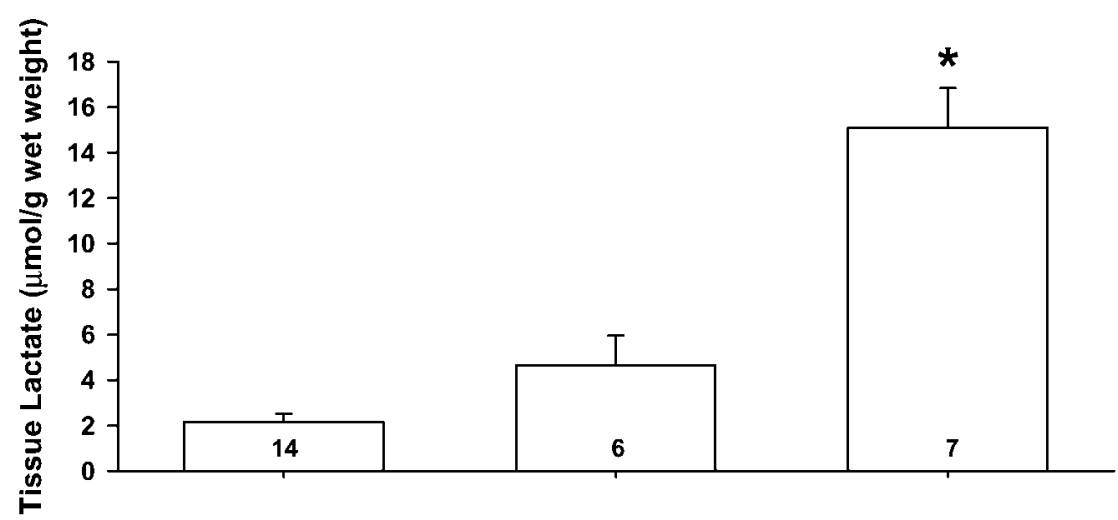

B

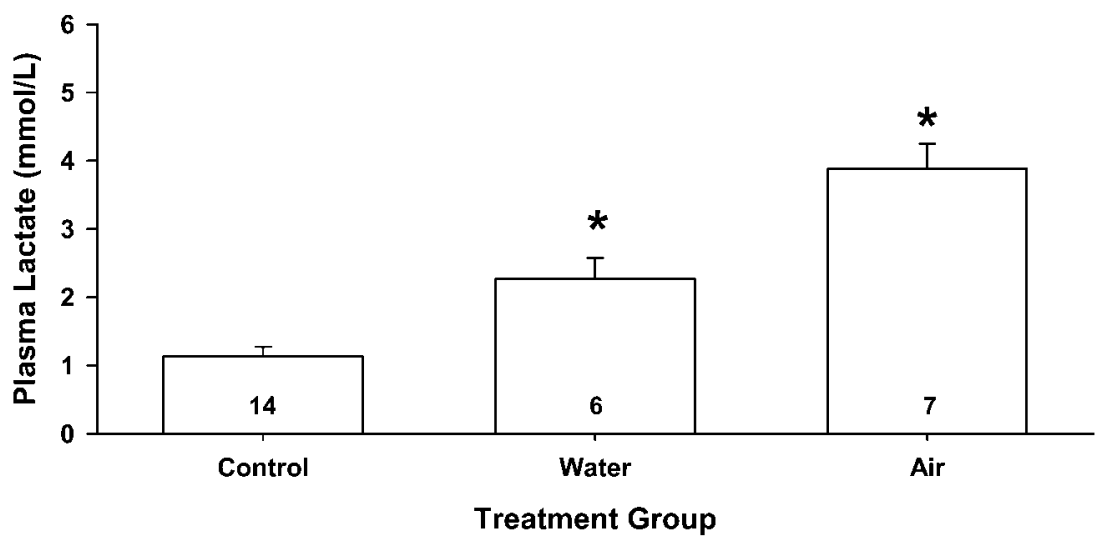

Figure 7.-(A) Tissue lactate and (B) plasma lactate concentrations in largemouth bass sampled after either air or water exposure during a simulated angling tournament weigh-in. Error bars show 1 SE, and sample sizes for the different components are given on each bar. Asterisks denote significant differences from the control group (ANOVA; Dunnett's test, $P<0.05$ ).

ably have an important impact on the physiological condition of largemouth bass following these events.

Our results may also provide some insight into the most common reasons for the mortality that occurs at some live-release tournaments. Previous studies have suggested that the fish mortality associated with these events may be due to the cumulative effects of numerous sublethal stressors arising from the tournament procedure (Schramm et al. 1987; Kwak and Henry 1995). If this is indeed the case, one of the most serious physiological consequences for fish in tournaments would likely be a significant reduction in plasma ion concentrations, which have been shown to result from chronic exposure to stress (Mazeaud and Mazeaud 1981; Wood et al. 1983; Carmichael et al. 1984; Wood 1991). In the present study, however, there were no significant decreases in plasma chloride concentration following any component of the simulated tournament, and changes in plasma osmolarity returned to control values following 24 $\mathrm{h}$ of recovery. Although fish undoubtedly experience some increases in ion losses across the gills during certain components of the tournament, these findings indicate that chronic stress is unlikely to be the main reason for mortality in these events. In contrast, the present results indicate that the most serious physiological consequence of the current tournament format may be extreme bouts 
A

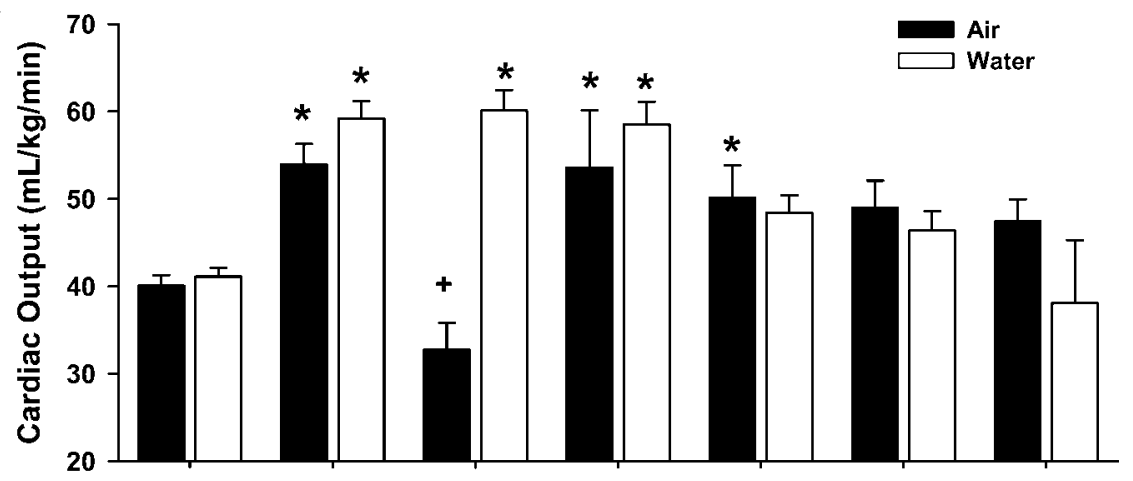

B

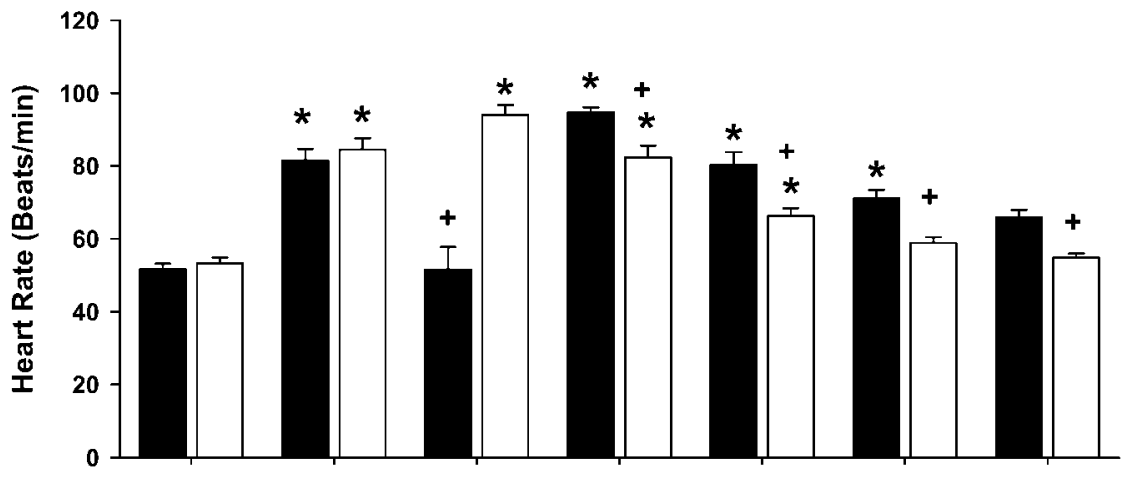

C

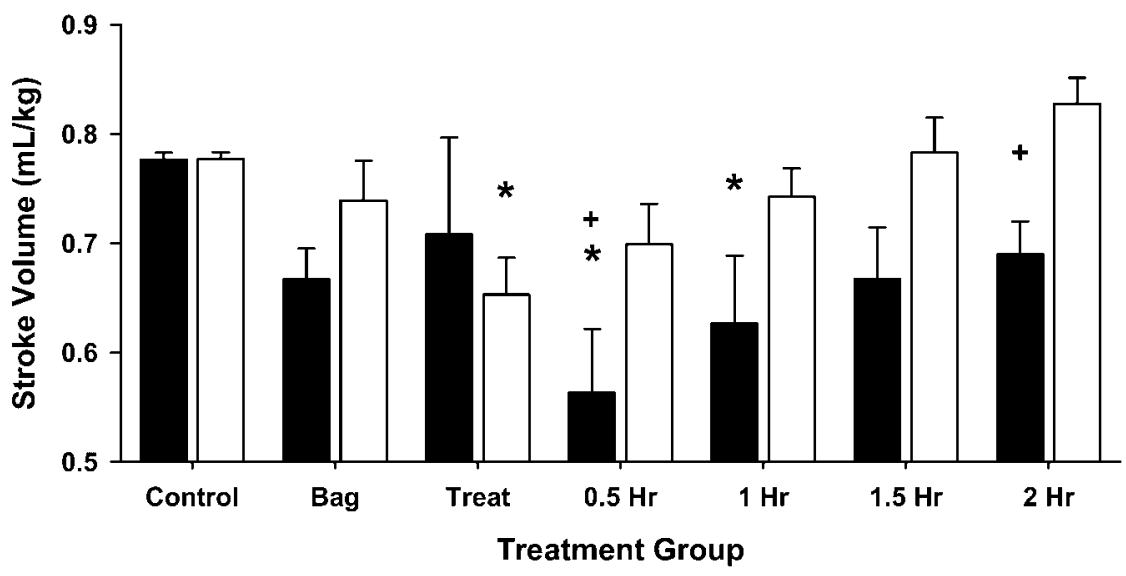

FIgURE 8.-(A) Cardiac output, $(\mathbf{B})$ heart rate, and (C) stroke volume of largemouth bass $(N=8)$ sampled after either air or water exposure during a simulated angling tournament weigh-in. Error bars show 1 SE. Asterisks denote significant differences from the control group within a treatment, and plus signs denote significant differences between air and water treatments at a given sampling time (two-way repeated-measures ANOVA; post hoc Student's $t$-test, $P<0.05)$.

of anaerobic activity. In the present study, these anaerobic bouts did not result in any fish mortality. In real tournaments, however, we have frequently observed that the severity of the anaerobic bout during the weigh-in may exceed that used in the present study. If adequate precautions are not taken, fish may also be exposed to aquatic hypoxia during confinement in the transfer bags prior to the weigh-in, or immediately following the weighin while being held in tanks or boats prior to re- 
lease. Because the weigh-in procedure already appears to cause a large anaerobic disturbance in tournament fish, it is likely that any further increases in this disturbance may result in significant fish mortality.

\section{Acknowledgments}

Financial support for this study was provided by grants from Shimano Canada, Ltd., and the Natural Sciences and Engineering Research Council of Canada (NSERC) Collaborative Research and Development Program to B.L.T. The Natural Sciences and Engineering Research Council of Canada also provided graduate support to C.D.S. and S.J.C. The authors express their appreciation for the excellent technical assistance provided by $\mathrm{M}$. Fortner and the logistical support of tournament organizers and the QUBS. Additional support for the cardiovascular assessments was provided by the Illinois Natural History Survey. J.D.K. thanks NSERC and the University of New Brunswick for funds.

\section{References}

Bennett, D. H., L. K. Dunsmoor, R. L. Hohrer, and B. E. Rieman. 1989. Mortality of tournament-caught largemouth and smallmouth bass in Idaho lakes and reservoirs. California Fish and Game 75:20-26.

Booth, R. K., J. D. Kieffer, K. Davidson, A. T. Bielak, and B. L. Tufts. 1995. Effects of late-season catch and release angling on anaerobic metabolism, acidbase status, survival, and gamete viability in wild Atlantic salmon (Salmo salar). Canadian Journal of Fisheries and Aquatic Sciences 52:283-290.

Boutilier, R. G., G. Dobson, U. Hoeger, and D. J. Randall. 1988. Acute exposure to graded levels of hypoxia in rainbow trout (Salmo gairdneri): metabolic and respiratory adaptations. Respiration Physiology 71:69-82.

Carmichael, G. J., J. R. Tomasso, B. A. Simco, and K. B. Davis. 1984. Confinement and water-qualityinduced stress in largemouth bass. Transactions of the American Fisheries Society 113:767-777.

Cooke, S. J., K. Dunmall, J. F. Schreer, and D. P. Philipp. 2001. The influence of terminal tackle on physical injury, handling time, and cardiac disturbance of rock bass. North American Journal of Fisheries Management 21:265-274.

Cooke, S. J., K. G. Ostrand, C. M. Bunt, J. F. Schreer, D. H. Wahl, and D. P. Philipp. 2003. Cardiovascular responses of largemouth bass to exhaustive exercise and brief air exposure over a range of water temperatures. Transactions of the American Fisheries Society 132:1154-1165.

Cooke, S. J., J. F. Schreer, D. P. Philipp, and D. H. Wahl. 2002. Physiological impacts of catch-and-release angling practices on black bass. Pages 489-512 in D. P. Philipp and M. S. Ridgway, editors. Black bass 2000: ecology, conservation, and management.
American Fisheries Society, Symposium 31, Bethesda, Maryland.

Eros, S. K., and C. L. Milligan. 1996. The effect of cortisol on recovery from exhaustive exercise in rainbow trout (Oncorhynchus mykiss): potential mechanisms of action. Physiological Zoology 69: 1196-1214.

Ferguson, R. A., and B. L. Tufts. 1992. Physiological effects of brief air exposure in exhaustively exercised rainbow trout (Oncorhynchus mykiss): implications for "catch-and-release" fisheries. Canadian Journal of Fisheries and Aquatic Sciences 49:11571162.

Fielder, D. G., and B. A. Johnson. 1994. Walleye mortality during live-release tournaments on Lake Oahe, South Dakota. North American Journal of Fisheries Management 14:776-780.

Goeman, T. J. 1991. Walleye mortality during a liverelease tournament on Mille Lacs, Minnesota. North American Journal of Fisheries Management 11:5761.

Gustaveson, A. W., R. S. Wydoski, and G. A. Wedemeyer. 1991. Physiological response of largemouth bass to angling stress. Transactions of the American Fisheries Society 120:629-636.

Hartley, R. A., and J. R. Moring. 1993. Observations of black bass (Centrarchidae) confined during angling tournaments: a cautionary note concerning dissolved oxygen. Aquaculture and Fisheries Management 24:575-579.

Hassid, W. Z., and S. Abraham. 1957. Chemical procedures for analysis of polysaccharides. Pages 3447 in S. P. Colwick, editor. Methods in enzymology, volume 3. Kaplan Academic Press, New York.

Hayes, D. B., W. W. Taylor, and H. L. Schramm, Jr. 1995. Predicting the biological impact of competitive fishing. North American Journal of Fisheries Management 15:457-472.

Kerr, S. J., and K. K. Kamke. 2003. Competitive fishing in freshwaters of North America: a survey of Canadian and U.S. jurisdictions. Fisheries 28(3):2631.

Kieffer, J. D. 2000. Limits to exhaustive exercise in fish. Comparative Biochemistry and Physiology 126A: 161-179.

Kieffer, J. D., M. R. Kubacki, F. J. S. Phelan, D. P. Philipp, and B. L. Tufts. 1995. Effects of catchand-release angling on nesting male smallmouth bass. Transactions of the American Fisheries Society $124: 70-76$.

Kwak, T. J., and M. G. Henry. 1995. Largemouth bass mortality and related causal factors during live-release fishing tournaments on a large Minnesota lake. North American Journal of Fisheries Management 15:621-630.

Lee, D. P., I. Paulsen, and W. Beer. 1993. Trends in black bass fishing tournaments in California, 19851989. California Fish and Game 79:1-12.

Lowry, O. H., and J. V. Passonneau. 1972. A flexible system of enzymatic analysis. Academic Press, New York.

Mazeaud, M. M., and F. Mazeaud. 1981. Adrenergic responses to stress in fish. Pages $49-75$ in A. D. 
Pickering, editor. Stress and fish. Academic Press, London.

McDonald, D. G., C. L. Milligan, W. J. McFarlane, S. Croke, S. Currie, B. Hooke, R. B. Angus, B. L. Tufts, and K. Davidson. 1998. Condition and performance of juvenile Atlantic salmon (Salmo salar): effects of rearing practices on hatchery fish and comparison with wild fish. Canadian Journal of Fisheries and Aquatic Sciences 55:1208-1219.

Milligan, C. L. 1996. Metabolic recovery from exhaustive exercise in rainbow trout. Comparative Biochemistry and Physiology 113A:51-60.

Payer, R. D., R. B. Pierce, and D. L. Periera. 1989. Hooking mortality of walleyes caught on live and artificial baits. North American Journal of Fisheries Management 9:188-192.

Pearson, M. P., L. L. Spriet, and E. D. Stevens. 1990. Effect of sprint training on swim performance and white muscle metabolism during exercise and recovery in rainbow trout (Salmo gairdneri). Journal of Experimental Biology 149:45-60.

Pereira, D. L., M. G. Halverson, R. E. Ramsell, and M. T. Drake. 2002. Changes in the largemouth bass fishery of Lake Minnetonka, Minnesota: evidence from tournament monitoring. Pages 477-487 in D. P. Philipp and M. S. Ridgway, editors. Black bass 2000: ecology, conservation, and management. American Fisheries Society, Symposium 31, Bethesda, Maryland.

Plumb, J. A., J. M. Grizzle, and W. A. Rogers. 1988. Survival of caught-and-released largemouth bass after containment in live wells. North American Journal of Fisheries Management 8:325-328.

Richards, J. G., G. J. F. Heigenhauser, and C. M. Wood. 2002. Lipid oxidation fuels recovery from exhaustive exercise in white muscle of rainbow trout. American Journal of Physiology 282:R89-R99.

Scarabello, M., G. J. F. Heigenhauser, and C. M. Wood. 1991. The oxygen debt hypothesis in juvenile rainbow trout after exhaustive exercise. Respiration Physiology 84:245-259.

Schramm, H. L., Jr., M. L. Armstrong, N. A. Funicelli, D. M. Green, D. P. Lee, R. E. Manns, Jr., B. D. Taubert, and S. J. Waters. 1991. The status of competitive sport fishing in North America. Fisheries 16(3):4-12.

Schramm, H. L., Jr., P. J. Haydt, and N. A. Bruno. 1985. Survival of tournament-caught largemouth bass in two Florida lakes. North American Journal of Fisheries Management 5:606-611.
Schramm, H. L., Jr., P. J. Haydt, and K. M. Portier. 1987. Evaluation of prerelease, postrelease, and total mortality of largemouth bass caught during tournaments in two Florida lakes. North American Journal of Fisheries Management 7:394-402.

Schreer, J. F., S. J. Cooke, and R. S. McKinley. 2001. Cardiac response to variable forced exercise at different temperatures: an angling simulation for smallmouth bass. Transactions of the American Fisheries Society 130:783-795.

Shupp, B. D. 1979. 1978 status of bass fishing tournaments in the United States. Fisheries 4(6):11-19.

Sokal, R. R., and F. J. Rohlf. 1995. Biometry, 3rd edition. Freeman, New York.

Summerfelt, R. C., and L. S. Smith. 1990. Anesthesia, surgery, and related techniques. Pages 213-272 in C. B. Schreck and P. B. Moyle, editors. Methods for fish biology. American Fisheries Society, Bethesda, Maryland.

Suski, C. D., S. S. Killen, M. B. Morrissey, S. G. Lund, and B. L. Tufts. 2003. Physiological changes in largemouth bass caused by live-release angling tournaments in southeastern Ontario. North American Journal of Fisheries Management 23:760-769.

Wang, Y., G. J. F. Heigenhauser, and C. M. Wood. 1994a. Integrated responses to exhaustive exercise and recovery in rainbow trout white muscle: acid-base, phosphogen, carbohydrate, lipid, ammonia, fluid volume, and electrolyte metabolism. Journal of Experimental Biology 195:227-258.

Wang, Y., M. P. Wilkie, G. J. F. Heigenhauser, and C. M. Wood. 1994b. The analysis of metabolites in rainbow trout white muscle: a comparison of different sampling and processing methods. Journal of Fish Biology 45:855-873.

Weathers, K. C., and M. J. Newman. 1997. Effects of organizational procedures on mortality of largemouth bass during summer tournaments. North American Journal of Fisheries Management 17: $131-135$.

Wilde, G. R. 1998. Tournament-associated mortality in black bass. Fisheries 23(10):12-22.

Wood, C. M. 1991. Acid-base and ion balance, metabolism, and their interactions after exhaustive exercise in fish. Journal of Experimental Biology 160: 285-308.

Wood, C. M., J. D. Turner, and M. S. Graham. 1983. Why do fish die after severe exercise? Journal of Fish Biology 22:189-201.

Zar, J. H. 1999. Biostatistical analysis, 4th edition. Prentice Hall, Englewood Cliffs, New Jersey. 